\title{
Beyond Carbon: Enabling Justice and Equity in REDD+ Across Levels of Governance
}

\author{
$\underline{\text { Heike Schroeder }}^{1}$ and Constance McDermott ${ }^{2}$
}

Key Words: equity; justice; multi-level governance; REDD+;

The global nature of climate change and the globalization of environmental governance have highlighted the challenges of enabling justice and equity across diverse societies and multiple levels of governance. At the center of these challenges are ongoing debates over the distribution of rights and responsibilities for environmental and social impacts - e.g., to what degree are developed countries responsible for climate disasters and developing countries responsible for adapting to them?; what rights do global versus national and local actors have to steer decision-making?; and what are the relative rights of present versus future generations or human versus non-human species? These debates have been variously framed in normative terms, drawing on particular norms of justice or equity as de facto goals in and of themselves, or based in instrumentalist arguments, e.g., the importance of justice and equity to achieving lasting emissions reductions. Perhaps nowhere have these debates been more complex and multi-faceted than under Reducing Emissions from Deforestation and Degradation (REDD+), a mechanism of the UN Framework Convention on Climate Change (UNFCCC).

The UNFCCC adopted REDD+ as a climate mitigation mechanism in recognition that carbon emissions from tropical forest loss were generating some $13-17 \%$ of global anthropogenic greenhouse emissions, and that avoiding deforestation could be a cheap mitigation option (Stern 2006). REDD+, as defined by the UNFCCC, is a three-phase mechanism culminating in resultsbased payments to developing countries for reducing carbon emissions in exchange for significant finance from developing countries (Angelsen et al. 2012). However the apparent centrality of carbon, and of national sovereignty, to UNFCCC REDD+ accounting belies the diverse reasons that actors have or have not chosen to support it (e.g., Lyster et al. 2013).

Arguably very few actors view tropical forests as primarily sources or sinks of carbon. They have been promoted variedly as constituting a global commons resource, sovereign resources and local commons resources (Brown 2001). Forests are valued for a wide range of reasons, from their role in supporting the majority of terrestrial biodiversity to their role in providing livelihoods for an estimated 1.6 billion people, including 60 million indigenous peoples and many other poor and vulnerable populations (World Bank 2004). REDD+ stakeholders vary in the priorities they place on these different values, leading to conflicts over the governance of REDD+ (McDermott et al. 2012). These conflicts are exacerbated by a widespread lack of clarity over land and resource rights in tropical forest landscapes. For REDD+ to have a significant impact on emissions reduction, it must transform the governance and economic incentives attached to vast swathes of these contested and diversely valued forest landscapes. As a result,
REDD+ has become inextricably entangled in fundamental debates about justice and equity from local to global levels.

This Special Feature, therefore, aims to shed light on how various scholars are examining the complex landscape of justice and equity in REDD+, with particular attention to the multiple levels of governance in which they play out (Sikor et al. 2010; Schroeder 2010). There is a vast range of literature on justice and equity, spanning diverse disciplines, from philosophy to law, political science, international relations, social psychology and beyond. In order to map out the perspectives covered in this Special Feature, we draw in particular on several recent publications that synthesize this broader literature and explicitly relate it to REDD+. Sikor (2013) examines the 'justices and injustices' of market-based payments for environmental services (PES), including payments under the REDD+ mechanism. Similarly, McDermott et al. (2013) establish an 'Equity Framework' for mapping out the different parameters, dimensions and tradeoffs for equity in PES and REDD+.

As is evident from both of these works, justice and equity are closely related concepts and both appear frequently in international environmental negotiations. We have adopted both terms in this Special Feature to encompass the broad challenge of fairness in REDD+, including the respect for human rights implicit in the concept of justice as well as the distribution of costs and benefits implicit in the concept of equity. ${ }^{[1]}$ More critical than the choice of terms, is that we share with Sikor (2013) and McDermott et al. (2013) a view of justice, equity and fairness as inherently socially constructed. That is, rather than attempt to establish universal principles of just and equitable behavior, as per the approach of ethical theorists such as Rawls (1971), these authors highlight the importance of understanding who is involved in framing what is just or unjust and how. We likewise identify the theme of framing as a common and important thread throughout many of the articles included in this Special Feature. Furthermore, Sikor (2013) and McDermott et al. (2013) both highlight the common distinction between procedural and distributive dimensions of justice and equity. Several of the articles in this Special Feature help to parse out these differences, with a particular focus on local-level participation and benefit distribution.

The framing of REDD+ occurs in a multitude of arenas both inside and outside of formal REDD+-related institutions. Framing can happen through direct interventions in the design of REDD+ under the UNFCCC. For example, the decision to channel REDD+ payments through national governments has established the central state as a key actor in REDD+ (Phelps et 
al. 2010). Likewise, the inclusion of safeguards in the 2010 Cancun Agreement has prioritized the rights of indigenous and local communities, while omitting mention of migrants or other vulnerable groups (Forsyth and Sikor 2013). Framing also occurs through the interpretation of REDD+ by the myriad funding agencies, governments, private certification schemes and local actors involved in implementing REDD+-related activities (McDermott et al. 2012). Justice and equity may be understood differently by all of these different actors and at different levels of governance (Di Gregorio et al. 2013).

Of particular concern to the authors in this Special Feature, however, are the broader discourses around REDD+ and how they appear to be shaping who is included and excluded from REDD+ decision-making, and/or defining the scope of REDD+ as primarily about carbon or more holistic forest governance (Visseren-Hamakers et al. 2012). Similarly, some authors query whether REDD+ policies and approaches are focused only on the symptoms or on the social and political root causes of inequality, i.e., "contextual equity" (Di Gregorio et al. 2013).

For example, Di Gregorio et al.'s (2013) analysis of the media coverage of equity under REDD+ highlights a disproportionate focus on national equity concerns over and above that of the participation and recognition of local and indigenous rights. Pokorny et al. (2013), who focus on the implementation of REDD+-related activities in the Amazon, find the predominance of an "old environment and development paradigm" that likewise privileges external actors over local communities. According to these authors, REDD+ favors Western, scientific expertise over local knowledge. By thus failing to learn from locally adapted knowledge and practices, REDD+ interventions are at risk of failing like the multitude of development projects before them.

While Di Gregoio et al. (2013) and Pokorny et al. (2013) thus view the dominance of international discourse as locally damaging, Savaresi (2013) and Wallbott (2014) highlight the potential for such discourse to empower some marginalized voices. Specifically, Savaresi (2013) points to the need for greater integration of international human rights discourse into REDD+ as a means to improve equity outcomes. Wallbott (2014) follows the involvement of indigenous rights activists in REDD+, noting how they have "imported power" from other fora such as the UN Declaration on the Rights of Indigenous Peoples (UNDRIP) to strengthen their rights under REDD+.

Some countries have already taken a strong stance on the importance of making REDD+ a poverty alleviating tool, such as Vietnam (Di Gregorio et al. 2013). In contrast, Pokorny et al. (2013) find that where initiatives were focused on achieving environmental goals this often created restrictions and bureaucratic barriers for local forest users, for example the legal prohibition of raising buffalos in the extractive reserve Porto do Moz, in Pará, Brazil (Pokorny et al. 2013). They find this to be due to poor coordination and lack of coherence with priority policy areas, as well as a lack of engagement with local smallholders to generate sustainable development pathways in rural areas. This leads these authors to conclude that REDD+ projects may have positive social and environmental outcomes only if they "build on the capabilities of the wide range of local natural resource managers to undertake efficient resource management and conservation" (Pokorny et al. 2013:2).
The focus of Rival (2013), like Pokorny et al. (2013), is on whether or not REDD+ can foster a more holistic approach to REDD+ that resonates with local priorities. Through review of one REDD+ initiative and two non-REDD+ initiatives in Brazil and Ecuador, Rival (2013) highlights the positive potential of "hybrid approaches" that integrate payments for ecosystem services with state-based efforts at landscape level planning. She notes how these projects are "uniquely fitted to the particular ... contexts in which they took root" and thus have achieved success in "citizen mobilization". She furthermore cautions that a transition to a purely results-based approach to REDD+ could undermine the development of such synergistic relationships.

Several of the articles in this Special Feature are focused at the local level on specific procedural and/or distributive dimensions of justice and equity in REDD+. In regards to the procedural dimension, Danielsen et al. (2013) draw on evidence from 289 vegetation plots in Southeast Asia that community-based monitoring under REDD+ can be as accurate and reliable as that of professional foresters. They also report on the underutilization of community monitoring to date, and argue for its potential to promote a more just REDD+.

Krause et al. (2013) draw lessons for REDD+ from a case study of Sociobosque in Ecuador as a state-based forest carbon payment scheme. They found minimal participation of civil society in its design. However, interviews with over 100 local participants in the scheme revealed generally positive perceptions of the democratic nature of decisions regarding participation in the program. Levels of understanding in the nature of their commitments under the program were, however, quite low, calling into question the overall depth and quality of citizen participation. In regards to benefit distribution, the majority of respondents reported that their families had received no benefits from their community's participation in Sociobosque.

Finally, the article by Luttrell et al. (2013) reviews four years of the CIFOR Global Comparative Study on REDD+ to compare and contrast how benefit sharing is framed and operationalized in six countries across Africa, Southeast Asia and Latin America. They develop a typology of six different "benefit-sharing rationales", based on different definitions of equity, and locate the design of existing REDD+ projects within this typology. They find substantial variation in approaches to benefit-sharing among REDD+ projects and interventions. In response, they argue for the importance of participatory stakeholder debates within REDD+ countries and the need to arrive at consensus regarding a common understanding of equity and benefit sharing under REDD+.

The above case studies reinforce our understanding of justice and equity as socially constructed concepts, involving multiple parameters (or framings) and dimensions (procedural, distributive and contextual) and operating at multiple scales. They also point to mixed results from REDD+ actions to date. In regards to framing, the international media have emphasized equity issues among nation states over and above justice for indigenous and local communities. At the same time, some indigenous actors have managed to use REDD+ to import power' from human rights discourse to strengthen their influence over REDD+ decision-making. In regards to procedural justice at local scales, some authors have emphasized the potential for 
community monitoring of REDD+ as a vehicle for community empowerment. Others have found evidence of poor community participation in practice. None of the articles provide evidence of a significant re-distribution of material benefits as a result of REDD+ interventions.

Taken as a whole, these findings highlight the importance of ongoing holistic assessment of justice and equity in REDD+. While there may never be full agreement on what is fair multilevel governance, a better understanding of how REDD+ is actually unfolding provides invaluable opportunities for more informed stakeholder dialogue and learning.

${ }^{[1]}$ We also recognize that both justice and equity can be viewed as encompassing all of these issues equally.

Responses to this article can be read online at: http://www.ecologyandsociety.org/issues/responses. $\mathrm{php} / 6537$

\section{Acknowledgments:}

We are grateful for generous funding from the Asia-Pacific Network for Global Change Research ( APN) and the School of International Development, University of East Anglia.

\section{LITERATURE CITED}

Angelsen, A., M. Brockhaus, W. D. Sunderlin, and L. V. Verchot, editors. 2012. Analysing REDD+: challenges and choices. CIFOR, Bogor, Indonesia.

Brown, K. 2001. Cut and run? Evolving institutions for global forest governance. Journal of International Development 13:89-905. http://dx.doi.org/10.1002/jid.831

Danielsen, F., T. Adrian, S. Brofeldt, M. van Noordwijk, M. K. Poulsen, S. Rahayu, E. Rutishauser, I. Theilade, A. Widayati, N. T. An, T. N. Bang, A. Budiman, M. Enghoff, A. E. Jensen, Y. Kurniawan, Q. Li, Z. Mingxu, D. Schmidt-Vogt, S. Prixa, V. Thoumtone, Z. Warta, and N. Burgess. 2013. Community monitoring for REDD+: international promises and field realities. Ecology and Society. 18(3): 41. http://dx.doi. org/10.5751/ES-05464-180341

Di Gregorio, M., M. Brockhaus, T. Cronin, E. Muharrom, L. Santoso, S. Mardiah, and M. Büdenbender. 2013. Equity and REDD+ in the media: a comparative analysis of policy discourses. Ecology and Society. 18(2): 39 . http://dx.doi. org/10.5751/ES-05694-180239

Forsyth, T., and T. Sikor. 2013. Forests, development and the globalisation of justice. The Geographical Journal 179:114-121. http://dx.doi.org/10.1111/geoj.12006

Krause, T., W. Collen, and K. A. Nicholas. 2013. Evaluating safeguards in a conservation incentive program: participation, consent, and benefit sharing in indigenous communities of the Ecuadorian Amazon. Ecology and Society. 18(4): 1. http://dx.doi. org/10.5751/ES-05733-180401

Luttrell, C., L. Loft, M. F. Gebara, D. Kweka, M. Brockhaus, A. Angelsen, and W. D. Sunderlin. 2013. Who should benefit from REDD+? Rationales and realities. Ecology and Society. 18(4): 52. http://dx.doi.org/10.5751/ES-05834-180452
Lyster, R., C. MacKenzie, and C. McDermott. 2013. Law, Tropical forests and carbon: the case of REDD+. Cambridge University Press, Cambridge, UK. http://dx.doi.org/10.1017/ CBO9781139236904

McDermott, M., S. Mahanty, and K. Schreckenberg. 2013. Examining equity: a multidimensional framework for assessing equity in payments for ecosystem services. Environmental Science and Policy 33:416-427. http://dx.doi.org/10.1016/j.envsci.2012.10.006

McDermott, C., L. Coad, A. Helfgott, and H. Schroeder. 2012. Operationalizing social safeguards in REDD+: actors, interests and ideas. Environmental Science and Policy 21:63-72. http://dx. doi.org/10.1016/j.envsci.2012.02.007

Phelps, J., E. Webb, and A. Agrawal. 2010. Does REDD+ threaten to recentralize forest governance? Science 328:312. http://dx.doi. org $/ 10.1126 /$ science. 1187774

Pokorny, B., I. Scholz, and W. de Jong. 2013. REDD+ for the poor or the poor for REDD+? About the limitations of environmental policies in the Amazon and the potential of achieving environmental goals through pro-poor policies. Ecology and Society 18(2): 3. http://dx.doi.org/10.5751/ ES-05458-180203

Rawls, J. 1971. A theory of justice. Harvard University Press, Cambridge, MA.

Rival, L. M. 2013. From carbon projects to better land-use planning: three Latin American initiatives. Ecology and Society 18(3): 17. http://dx.doi.org/10.5751/ES-05563-180317

Savaresi, A. 2013. REDD+ and human rights: addressing synergies between international regimes. Ecology and Society. 18 (3): 5. http://dx.doi.org/10.5751/ES-05549-180305

Schroeder, H. 2010. Agency in international climate negotiations: the case of Indigenous Peoples and avoided deforestation. International Environmental Agreements: Politics, Law and Economics 10(4):317-332. http://dx.doi.org/10.1007/s10784-010-9138-2

Sikor, T. 2013. Introduction: linking ecosystem services with environmental justice, In: The Justices and Injustices of Ecosystem Services, edited by T. Sikor. Earthscan Publications, London, pp. $1-18$.

Sikor, T., J. Stahl, T. Enters, J. C. Ribot, N. Singh, W. D. Sunderlin, and L. Wollenberg. 2010. REDD-plus, forest people's rights and nested climate governance. Global Environmental Change 20 (3):423-425. http://dx.doi.org/10.1016/j.gloenvcha.2010.04.007

Stern, N. 2006. The Economics of climate change: the Stern review. Cambridge University Press, Cambridge, UK.

Visseren-Hamakers, I. J., A. Gupta, M. Herold, M. Peña Claros, and M. J. Vijge. 2012. Interdisciplinary perspectives on REDD+: editorial overview. Current Opinion in Environmental Sustainability 4(6):587-589. http://dx.doi.org/10.1016/j.cosust.2012.10.011

Wallbott, L. 2014. Indigenous peoples in UN REDD+ negotiations: "importing power" and lobbying for rights through discursive interplay management. Ecology and Society 19(1): 21. http://dx.doi.org/10.5751/ES-06111-190121

World Bank. 2004. Sustaining forests: a development strategy. World Bank, Washington, DC. http://dx.doi.org/10.1596/0-8213-5755-7 